\title{
ACCOUNTING AND CLIMATE CHANGE EFFECTS DISCLOSURES: EXAMINING ITS IMPACT IN CURTAILING EMERGING INFECTIOUS DISEASES
}

\author{
EFUT, Monday Richmond \\ Ph.D. Scholar, Department of Accountancy, Nnamdi Azikiwe University, Awka-Anambra State- \\ Nigeria. \\ Amarachi, Chiagoziem, (CNA) \\ Department of Finance and Investment, National Identity Management Commission, Abuja-Nigeria.
}

Article DOI: $\underline{\text { https://doi.org/10.36713/epra2220 }}$

\begin{abstract}
This study aimed at $X$-raying the role of accounting and climate change effects in the world. The study was purely empirical in nature and data and information were obtained from related literatures and articles. The study further purposed that the accounting profession can support organizational climate change impact disclosures. This study is an additional literature to the existing research and practice in environmental accounting disclosures and set the pace for future research and practice in this field of accounting.
\end{abstract}

KEYWORDS: Accounting, Climate change, Infectious Diseases, Disclosures.

\section{INTRODUCTION}

No one on earth will be surprised to hear that there is a worrying wild range of problems connected with environment and climate change. From extreme weather conditions to melting ice caps and the extinction of animal species. From deadly Lassa fever virus in Nigeria to the fast rising coronavirus in China; is a testimony to the severe effects of climate change on the earth and indeed the human race in this $21 \mathrm{st}$ century. Thus, "Environment is life". Martina, Jacqueline and Andrew(2015) posited that human interference with climate system is occurring and climate change poses severe risks for human and natural systems(Martina, Jaqueline \& Andrew(2015) Included in the 5th Assessment Report of the Intergovernmental panel on climate change(IPCC) is a clear message explaining the fact that since the 1950s, the atmosphere and ocean have markedly warmed, the amount of ice and snow have diminished, sea level has risen and greenhouse emissions have increased(IPCC,2014)

As the effects of climate change becomes more clearer, especially impacts related to changes in extreme weather, It is imperative to reflect on the costing, reporting and disclosures of the impacts and its resulting implications for corporate governance. It is also important that policy makers, stakeholders and decision makers in corporate organizations will desire information that are decision relevant to aid them in valuing the economic implications of climate effects to support cost-benefit-analysis, liabilities and identify risks.

West and Brereton (2013), noted that companies will benefit from climate change related disclosures in so many ways. Chief among them is that it will assist them in addressing broader questions bordering on how to measure climate change vulnerability, adaptive capacity as well as adaption cost and needs. More so, it 
has also been observed that investors, rating agencies and lenders are constantly demanding information on climate change impact and consequences to enable them make capital allocation decisions. (West and Brereton 2013).

Research findings by Reid and Toffel,(2009) indicates that a growing number of institutional investors are beginning to come together in groups such as the Global Investor Coalition on Climate change, with the sole aim of desiring companies to consider climate change activities and its impacts as part of their corporate governance agenda(Reid and Toffel,2009). In addition, Cogan, (2006) has emphasized that the increased investors' concern about climate change has been assumed to be responsible for the shareholderproxy activity, especially in the United States (Cogan, 2006). Concurring with Cogan(2006), Cotter and Najah,(2012), reaffirmed that the collective influence of institutional investors have greatly affected the extent and quality of climate change information provided in disclosures by companies(Cotter and Najah,2012).Furthermore, Reid and Toffel,(2009), posit that even in private politics, shareholders resolutions filed against companies increased the likelihood that company's practices will be consistent with climate change strategies(Reid and Toffel 2009).

In the opinion of Martina, Jacqueline and Andrew (2015) even voluntary reporting initiatives, such as Carbon Disclosure Project (CDP) are presently asking companies to report on the physical risk associated with climate change. In doing so, these companies have gone above their initial level of reporting on mitigation activities to expounding on the disclosures and reporting on the direct impact of climate change activities on the human race.

These developments pose greater challenges before companies. It will definitely require them to develop risk assessment methods to investigate climate and broader investor risks, to implement framework for evaluating disclosures options and to disclose climate change effects and risk. This study is particularly concerned with the role of Accounting in climate change effects disclosures. It is aimed at examining its impact in curtailing emerging infectious diseases in the world. This study contributes to this emerging area of accounting by synthesizing existing literature and prepare the space for other future research. It is also a first step in the direction of understanding how accounting profession can support disclosures of climate change, with a view to X-raying its impact in curtailing emerging climate and environment related diseases.

\section{BRIEF HISTORY OF ACCOUNTING AND ITS RELATIONSHIP TO NATURAL ENVIRONMENT.}

It was in the 1960s and 1970s that the need to consider the natural environment in accounting decisions was introduced for the first time (Beans and Fertig, 1971). It became clear at that time due to the fact that the environmental problems created by the activities of various companies around the world was impacting negatively on the environment and the idea came up that these problems could partly be handled by identifying, measuring and may be valuing the interactions and interchanges between the environment and these companies. It was discovered that contributions from different sources identified various methods for accounting for the environmental impacts. These include but not limited to input/output accounting( this has to do with analyzing the physical flow of inputs such as waste, energy, materials and output such as emission on waste)sustainable and full cost accounting(this has to do with the amount of money a company would have to spend to return the environment back to the state where it was at the beginning of the accounting period) and natural capital accounting(which has to do with accounting of natural capital such as; habitat or biodiversity cost which is usually not factored into pricing decisions) Matthew,(1997) in Martina, Jacqueline and Andrew(2015)

Furthermore, Martina, Jacqueline and Andrew (2015) asserts that it was studied and findings like the ones stated above that lead to the further research into the topic of environmental accounting and from the late 1980s and early 1990s, a whole lot of studies and literatures have come up highlighting that the accounting profession should be fully involved in studying the relationship between companies activities and the natural environment (Martina, Jacqueline and Andrew (2015)

Gray(1990) opined that, there is need for a paradigm shift which would allow for the inclusion of environmental and social issues into accounting literatures and practice, considering aspects such as compliance and ethical audits, waste and energy reporting, environmental impact assessment, environmental and social reporting and accounting for environmental assets and liabilities(Gray,1990). Subsequently, Elkington (1997) invented the term "triple bottom line" and explained that companies and organization should make it a point of duty to report on both their social and environmental performances and their annual financial performance. According to Martina, Jacqueline and $\operatorname{Andrew(2015),~it~was~}$ 
Elkington's research and publications that prompted other researchers to argue and propose that accounting could and should support companies and organization's efforts in addressing their environment and environmental performance(Elkington, 1997) in Martina, Jacqueline and Andrew(2015). Thus environmental accounting grew into a great field of research, including areas such as voluntary disclosures, (Deegan and Blounquist (2006), Ethical issues (Gray, 1997), costing of Externalities (Deegan 2008), and capital Markets impacts (Bachoo, 2013).

\section{IMPACTS OF CLIMATE CHANGE: EMERGING INFECTIOUS DISEASES}

According to Casti (1997), the scientific world have come up with a large body of evidence which shows that climate change is occurring and that the resulting impacts are presenting real and significant threats to the inhabitants of the world. Accordingly, the reports by the intergovernmental panel on climate change (IPCC), which summaries the latest body knowledge on climate change, show that the impacts of climate change such as rising temperatures, changes in sea levels and changes in ice and snows covers are already observable around the world.

Bryn (2020), recently noted that climate change had made the risks of novel diseases much more explosive. Furthermore, it had been observed that in recent years, scientists have linked most emerging infectious diseases to animals especially, wildlife. Much of that wildlife is being displaced by global warming and habitats loss, putting stressed species that are more susceptible to infection in close contact with humans. (Bryn 2020)

Will (2020), has explained that global warming can accelerate displacement by thawing, burning, flooding or drying out habitats in response to hotter temperatures, and stronger storms. As habitats change and people move and wildlife moves, they are going to be coming into contact more with each other" Increasingly close contact, in turn significantly raises the risk that an animal diseases will spill over into humans.

In the 1998 -1999 Nipah Virus outbreak in Malaysia that killed more than 100 people, for instance, researchers concluded that fruit bats dislodged by forest fires and an El Nino related drought began feeding on fruits trees grown on the same farms as pigs. The close proximity allowed the virus to jump from bats to pigs to farmers. It is believed that stressed animals, whether due to displacement or confinement in animal markets (like the case of Wuhan in China), are more susceptible to diseases.
Will(2020) further explained that the risk of pathogens emerging due to climate change is not limited to tropical regions of the globe alone, stating that researchers recently announced findings of 33 viruses ,28 of which were new to science that had been entombed for 15,000 years in ice cores within a melting glacier in Tibet. The scientist further revealed that in a worst scenario, the ice melt could release pathogens into environment, aiding the spread of these yet to be known virus on the human race. Likewise, Fair, and colleagues have recently reported that mosquitoes that can infect both humans and animals with diseases like Chikungunya, dengue and malaria are advancing northward and shedding more viral particles with warmer temperatures. Therefore, complex models that account for changes in climate, habitat and diseases epidemiology can help to predict where certain diseases will appear in the coming year or in another 30 years (Bryn, 2020)

In Nigeria, the dreaded Lassa fever, an offshoot of contact between the rats and the human food is a visible example of the impact of climate change on humanity. Researchers and scientists in Nigeria have attributed the emergence of the disease which has claimed about 532lives in the last three years to the displacement of rats from their natural habitat due to bush burning for hunting or preparation of land for farming. In effect, these rodents find their way to the abode of human, feed and infect human food with their urine; a major carrier of the Lassa virus. It is imperative to state that, environmental enlightenment and accountability by companies around the world to environmental issues is key to the amelioration of the emerging infectious diseases connected to the climate and environmental dysfunctions.

\section{DISCLOSURES OF RISKS CONNECTED WITH CLIMATE CHANGE IMPACTS.}

Greater number of institutional investors and interest groups are already campaigning for greater disclosures about climate change impacts, mainly as a result of the foreseen material negative financial effect, and also because of the current low disclosures levels (Stanny and Ely, 2008). In addition, Cotter and Najah (2012) affirm that these groups have the collective power to influence the extent and quality of disclosures (Cotter and Najah, 2012). Furthermore, it is expected that due to the expected increase in adverse impacts, including more frequent and severe weather extremes, financial accounting and reporting standards and other listing rules will require more explicit corporate risk disclosures on climate change (Martina, Jacqueline and Andrew, 2015) 
Below is a table showing emerging disclosures demands for risk associated with climate change impacts.

\section{Table 1}

EMERGING DISCLOSURE DEMANDS FOR RISKS ASSOCIATED WITH CLIMATE CHANGE IMPACTS.

\begin{tabular}{|c|c|c|c|}
\hline $\mathbf{S} / \mathbf{N}$ & BODY & & DETAILS \\
\hline 1. & $\begin{array}{ll}\text { International } & \text { Accounting } \\
\text { Board(IASB) } & \\
\text { International } & \text { Financial } \\
\text { Standard(IFRS) } & \end{array}$ & $\begin{array}{l}\text { Standard } \\
\text { Reporting }\end{array}$ & $\begin{array}{l}\text { The IASB is the independent standard setting body of } \\
\text { the IFRS Foundation.IFRS standard already address the } \\
\text { disclosure of wide variety of risks. A more explicit } \\
\text { integration of climate change risks in disclosure } \\
\text { standard is likely to occur in future as climate change } \\
\text { becomes more visible. }\end{array}$ \\
\hline 2. & \multicolumn{2}{|c|}{ Climate Disclosure Standard Board(CDSB) } & $\begin{array}{l}\text { The CDSB is a consortium of global business and } \\
\text { environmental non-governmental organizations } \\
\text { (NGO'S). The CDSB climate change reporting } \\
\text { Framework is a voluntary reporting framework } \\
\text { designed for companies to disclose climate change- } \\
\text { related risks and opportunities and implications for } \\
\text { shareholder value in their financial reports. }\end{array}$ \\
\hline 3. & \multicolumn{2}{|l|}{ Carbon Disclosure Project(CDP) } & $\begin{array}{l}\text { The CDP request on behalf of institutional investors' } \\
\text { information from thousands of the world's largest } \\
\text { companies on their greenhouse gas emission, energy } \\
\text { use and climate change risks and opportunities. } \\
\text { Disclosure takes place via the CDP questionnaire and it } \\
\text { is voluntary. }\end{array}$ \\
\hline
\end{tabular}

Source: Adapted from Martina, Jacqueline and Andrew (2015)

\section{CONCLUSION AND RECOMMENDATION}

Undoubtedly, climate change impact on humanity is enormous and will even be more in the future. Therefore as climate change impacts continue to increase the accounting function as it pertains to legislation around greenhouse gas mitigation and disclosures must be emphasized. It is also important to focus on the creation of the best practice approach for organizations to realize how climate change impact can be accounted for. Further to the above, there ought to be concerted efforts aimed at the development of a consolidated approach to methodological avenues for accounting for the distribution of costs and benefits across different time scales. Also increase awareness around the need to report on climate change disclosures should be emphasized.

\section{REFERENCES}

1. Bachoo K.R (2013), Firm value and the quality of sustainability reporting in Australia, Australian Accounting Review 23, 67-87.

2. Beans, F.A and Fertig P.E (1971), Pollution Control through social cost conversion, The Journal of Accountancy 132, 37-42.

3. Bryn, $N$ (2020), Climate change makes the risk of Novel Diseases much more Explosive.

4. Casti, J.L (1997), Would-be Worlds; How Simulation is changing the frontiers of science (Willey, New York).

5. Cogan, D.G. (2006), Corporate Governance and climate change: Making the connection (Ceres, Boston, MA).

6. Cotter J.D and Najah.M (2012), Institutional Investor influence on global climate change disclosures practices .Australian Journal of Management 37(2), 169-187.

7. Deegan, C (2008), Environmental costing in Capital Investment decision; electricity distributions and the choice of Power poles. Australian Accounting Review 18, 2-15. 


\section{EPRA International Journal of Research and Development (IJRD)

8. Elkington, J (1997), Cannibals with Forks: The Tripple Bottom line of 21st Century Business (Capstone, Oxford, UK)

9. Gray, R.H (1990), The Greening of Accountancy; The profession after Pearce (chattered Association of Certified Accountants, London, UK).

10. IPCC, (2014), Climate change 2014: Impacts, adaptation and Vulnerability; Contribution of working Group 11 to the Fifth Assessment Report of the Intergovernmental panel on climate change.

11. Martina, K.L. Jacqueline and Andrew G. (2015) The role of Accounting in supporting adaptation to climate change.UQ Business School, The university of Queensland.

12. Matthews, M.R (1997), Twenty-five years of social and environmental accounting research. Is there a silver jubilee to celebrate? Accounting, Auditing and Accountability journal 10,481-531.

13. National Centre for Disease Control Situational Report Number 47: 2019 Lassa fever Outbreak in Nigeria. (2019)
14. Olarewaju, K (2020) Nigeria: Death toll from Lassa Fever Outbreak hits 70, Health, Africa. National Centre for Disease Control. (13-02-2020).

15. Reid, E.M and Toffel M.W (2009), Responding to Public and Private Politics: Corporate disclosure of climate change strategies: Strategic Management Journal 30, 1157-1178.

16. Stanny, $E$ and Ely, E (2008), Corporate Environmental Disclosures About the effect of Climate change. Corporate Social Responsibility and Environmental Management 15,338-348.

17. West, J and Brereton.D, (2013), Climate change Adaptation in industry and Business: A framework for Best practice in Financial Risk Assessment, Governance and Disclosure.

18. Will, $S$ (2020), Why Won't WHO Declare an Emergency over Coronavirus? 